\title{
Investigating the Indonesia Folk Song Arrangement in Six Choir Competition, 2019
}

\author{
Rachel Mediana Untung ${ }^{1}$, Wisma Nugraha Ch., R. and Victor Ganap \\ Program Studi Pengkajian Seni Pertunjukan dan Seni Rupa Sekolah Pascasarjana \\ Universitas Gadjah Mada Yogyakarta
}

\begin{abstract}
This study is aimed at investigating the trend of a folk song arrangement in six Choir Competitions Folklore Category, 2019. It is specifically focused on investigating three things: the tendency of arrangers' names, the title of the origin of folk songs performed in the competitions, the characteristic of the arrangement, and the relationship between the arrangers and the national choir competitions committee. The reason for choosing the topic is that such a folk song arrangement is one of the key factors in conducting a choir competition, folklore category. As for the research method, it is more on music behavior in a relational territory. Therefore, it used a document study and qualitative research design. In this case, the researcher observed in six choir competitions and interviewed the arrangers, choir leaders, and musicians taking part in the competitions. The findings revealed that the most frequently used arrangement was Ken Steven's "Cikala Le Pong Pong." The most popular arranger was Budi Susanto Yohanes, and Java and Madura were the two origins from which most of the folk songs were performed in choir competitions. The characteristic of the most popular one is its unique arrangement in the form of vibrant music rhythm and body percussion. It revealed that an arranger is the first key agent in a systemic social-organization mechanism like in a choir competition.
\end{abstract}

Keywords: folk song arrangement; arranger; choir competition

\begin{abstract}
ABSTRAK
Pelacakan Aransemen Lagu Rakyat Indonesia dalam Enam Lomba Paduan Suara pada Tahun 2019. Riset ini dilakukan untuk mencermati tren pemilihan judul aransemen dalam Kategori Lagu Rakyat pada enam Lomba Paduan Suara tahun 2019. Riset ini fokus meneliti tiga hal, yaitu pertama, tren berdasarkan nama aranjer, judul aransemen, asal daerah; kedua, karakter dari aransemen, dan ketiga relasi antara aranjer dengan penyelenggara kompetisi lomba paduan suara nasional. Hal ini penting dilakukan karena hadirnya aransemen lagu rakyat memantik rantai penyelenggaraan lomba paduan suara. Metode menggunakan penelitian dokumen dan kualitatif karena ranah penelitian pada perilaku musik. Statistik sederhana digunakan untuk mengidentifikasi aransemen berdasarkan judul, nama aranjer, dan asal daerah lagu rakyat. Peneliti hadir melakukan observasi pada enam lomba paduan suara dan melakukan wawancara kepada aranjer, pelatih paduan suara, dan musisi yang berperan dalam penyelenggaraan lomba. Temuan menunjukkan aransemen paling populer adalah "Cikala Le Pong Pong" karya Ken Steven yang dikenali karena ritmis yang rancak dan penggunaan perkusi tubuh. Nama Budi Susanto Yohanes menjadi aranjer yang paling sering muncul dan aransemen lagu rakyatnya telah dinyanyikan oleh banyak kelompok paduan suara. Daerah Jawa dan Madura menjadi asal daerah yang paling sering digunakan sebagai sumber inspirasi para aranjer. Aranjer merupakan agen pertama dalam suatu mekanisme organisasi sosial yang mengarah pada penyelenggaraan lomba yang sistemik.
\end{abstract}

Kata kunci: aransemen lagu rakyat; aranjer; lomba paduan suara

1 Correspondence: Universitas Kristen Satya Wacana, Jalan Diponegoro 52-60 Salatiga Jawa Tengah. E-mail: rachel.mediana.u@ugmail.ac.id; mediana.untung@uksw.edu; HP.: 08563789870. 


\section{Introduction}

Almost in any choir competition, "folk song" or "folklore" is considered to be the most preferred musical genre category. It is indicated form the number of participants choosing the category. For example, in the $10^{\text {th }}$ Sapta Gita choir competition - a national choir competition held in 2018, in Semarang-this category was chosen by 14 group-participants while the other genre categories ware chosen only by maximumly 10 group-participants. Another example is in the 3rd Choral Orchestra Folklore Festival on December, $17^{\text {th }}-20^{\text {th }}$, the genre was chosen by 17 group-participants while the other genre categories were chosen only by maximumly 7 group-participants.

The category of folk song or "lagu rakyat" in this study refers to a musical genre category in a choir competition representing a song from a certain region of a country. Initially, it is originated by the people of a certain region by a cultural definition, not a geographical definition. Since it exists in a cultural group of certain region, inevitably, it is often referred to "lagu daerah" — a song from a particular region. Furthermore, the idea of folk song is originated from both oral and written traditions but mostly passed by an oral tradition. As for the composition, it reflects a specific cultural expression of a certain ethnic group as manifested in its song, dance moves, and musical instruments.

The fact that more group-participants in choir competitions choose folklore category leads into the more versions of choir arrangement. This happens because this category is one of the open categories so the participants can choose any folk song they like. From this phenomena, I see that a song arrangement can be one of the key elements for conducting a choir competition. Accordingly, this study needs to be done as a preliminary study for exploring the existence of folklore category viewed from sociology of music.

This study is aimed at analyzing the arrangement of Indonesian folk songs and the role of the arrangers in six choir competitions held in 2019. The study is focused on the relationship between arrangement, arranger, and choir competitions. To achieve the objective, this study was guided with three research questions. First, what is the trend of song-arrangement choice in terms of title, arranger, and origin of the folk songs? Second, refer to the most popular folk songs performed in the national choir competition, what are the characteristics of folk song arrangement? Third, what are the roles and relationship between the arranger and the choir competition committee?

For the sake of originality, the previous studies of relevant topics need to be presented. First, a textual analysis of folk song arrangement score used for a choir was done by several undergraduate and graduate students for their thesis accomplishment. The analysis commonly used musicology approach in undergraduate to analyze one of the musical elements: form, melody, harmony, rhythm, dynamic, time, etc. Graduate students usually use more than two approaches, for example, Mei Artanto (2016) analyzed the arrangement score of folk song used in a folk song choir competition from the view of musicology and performance studies. In this study, he observed the formal object of a musical- score transfer that follows its agent of change. As the object of the study, he used the arrangement score of Singgih Sanjaya's "Nyanyian Negeriku". It is a medley of nine folk songs accompanied with an orchestra. The arrangement was in the form of score and performed in a performance. It shows a transit (a process of transferring the work of art to something beyond geographical and social boundaries). The result of the study showed that both the targeted agents: arranger and event organizer have political goals for their benefits.

This is similar to studies conducted by Epifani Omega, G.R. Lono Lastoro Simatupang, dan Royke B. Koapaha (Omega et al., 2019). The difference is on the object. Omega analyzed the presentation of "Dewa Ayu Janger" arrangement performed by Immanuel Choir, Universitas Kristen Immanuel Choir Yogyakarta. "Dewa Ayu Janger" consists of two folk songs "Dewa Ayu" and "Janger" from Bali arranged by Yohanes Dwi Pramono Mahardika. Specifically, Omega analyzed the presentation of choir arrangement performance from the view of musicology and performance 
studies. A comprehensive analysis in the study was focused on four elements: sound, agent, musical work, and listeners. The most interesting result is on the piercing-like sound as the special features of Balinese sound production, which is different from the western vocalization technic. According to Small (Small, 1998: 11), such a study, as two studies before, can be connected to musicking behaviours, which is related to my present study.

In response to the political goals in the previous paragraph, Theodor Adorno (Dasilva, 1984: 11) argued that composition itself is considered as a political action. In this way, a composer consciously makes use of his/her musical capacity and of variety of musical elements to create a work of music. If composition is a process of creating a work of music from an abstract score to a written score, similarly, an arrangement is also about creating a work of music. However, it recreates a work of music into a new composition (Boyd, 2002: 65). From the view of sociology of music, such a musical action or behaviour is called a political action (Dasilva, 1984: 11).

In this study, a musical arranger does a political action by arranging ethnic musical elements in his/her folk song arrangement. Besides a political action, such an arrangement of musical composition creates a reality, "a maker of music history" (Dasilva, 1984: 14). In addition, $\mathrm{He}$ argued that a composer or an arranger makes use of a variety of musical elements to present a musical reality. In the same view, Lono Simatupang (2013) states that composers or musicians create musical compositions in order to be performed, so that the staging event becomes an important study. This view shows how a composer or arranger is able to arrange musical elements into a musical composition as an event. This opinion is in line with Christoper Small's musicking.

In his book "Musicking", Christopher Small (1998) explained that musicking is a verb, from the word "music" and "ing", and refers to creating, training, listening, and performing a work of music. From the definition, the action of composing is a part of musicking. It is a musicking because it is a work of music that needs to be performed. In another word, a music player needs the work of music to perform. Vice versa, the work of music provide a place for the music players to perform.

A composer or arranger is devoted him/herself to create or to present things related to sounds. Along with the social need of organization, many of arrangers or composers bring about an ethnic musical genre to work with the "sounds". One of the examples is arranging folk-song scores for a choir. A choir with its voice classifications soprano, alto, tenor, and bass is always understood as a musicology term. As for a folk song, is commonly understood as a part of ethnomusicology. When an arranger is arranging an ethnic music, he/she must be doing some musical adjustments. Dealing with two approaches to produce one thing must not be easy. In the perspective of musicology, adjusting process like arranging or composing can threaten the music originality. Many musicians and ethnomusicologists compose and also do research in order to develop the authenticity of music in certain communities. Noted are Zulkarnaen Mistortoify, Timbul Haryono, Lono L. Simatupang and Victorius Ganap (2010); Ronaldi and Pande Made Sukerta (2013); Rasita Satriana, Timbul Haryono and Sri Hastanto (2014); Sri Hermawati Dwi Arini, Didin Supriadi and Saryanto (2015); Sri Rustiyanti (2017); Alrik Lapian and Aton Rustandi Mulyana (2017); Yandri Syafputra (2017); Firmansyah, G.R. Lono Lastoro Simatupang, Hermien Kusmayati, and Wiwik Suhastami (2019); Rustim, Wisma Nugraha Ch. R and G.R. Lono Simatupang (2019) they are scholars which compose and held research in tradition music from regions in Indonesia in the sake of originality.

Furthermore, studies conducted by Roosmegawaty, Lono Simatupang and Victor Ganap (2018) revealed similar results in a different spirit. The study was about the special feature of Batak Toba singing style andung. This singing style originally for a funeral ceremony has transformed into the popular- music genre andung-andung in Batak Toba. However, it remains to keep the melancholy as it is aimed at expressing one's condolence of someone's death. As a popular song, it is now accompanied with band and Batak Toba's traditional music. Research conducted by Martarosa (2017) shows the occurrence of hybrid 
music in coastal areas which is known as gamat music. The acceptance of musical elements outside of its local traditions led to continuous adjustments that in turn gave rise to new musical forms. The above research shows that the creative process occurs when adapting to the conditions of a plural society.

Those studies above indicate that there is a mutual interest in preserving the work of art in one hand, and in developing creativity for the work of art on the other hand. This study refers to treating an arrangement as one's creativity. i.e. an arranger's creativity. It is a creativity in composing a new form of creation based on the original work of art. Composer or etnomusicologist need to reseach deeply of musical elements of traditional music outside from their culture. This effort can be assisted by an institution that provides information on ethnic music, namely the World Music Source Center which was established in Surakarta (Santosa, 2015). Folk song choir arranger could use this institution to enrich their work. In this situation, arranger not only do creativity in their work, but they do a political action, that is by arranging ethnic musical elements in his/her folk song arrangement and to fullfill the requirement from the event organizer of a choir competition.

\section{Methodes}

This study is a qualitative study in nature focusing on musical behaviour. The musical behaviour is closely related to the role of people preforming the musical behaviour and the relationshiop among one and another. To reveal the musical behaviour, the researcher observed six choir competitions. First, the $9^{\text {th }}$ Brawijaya Choir Festival. It was held in Malang, from February, $6^{\text {th }}$ to $10^{\text {th }}, 2019$. Second, Rhaposodie Indonesia Choir Festival. It was held from April, $13^{\text {th }}$ to $14^{\text {th }}, 2019$ in Jakarta. Third, the $7^{\text {th }}$ Satya Dharma Gita Choir Festival, from Agustus 27 $7^{\text {th }}-31^{\text {st }}, 2019$ in Semarang. Fourth, The $1^{\text {st }}$ Toraja Highland Choir Festival. It was held from September, 19 $9^{\text {th }}-22^{\text {th }}, 2019$ in Makale, South Sulawesi. Fifth, Lomba Paduan Suara Universitas Gadjah Mada. It was held from November, 1-3, in Yogyakarta. Sixth, the last one,
The 3rd Choral Orchestra Folklore Festival. It was conducted from Desember, 17-20, in Yogyakarta.

Apart from those competitions, some others were also done in some areas in Indonesia. For example, the $10^{\text {th }}$ Bali International Choir Festival held on July, $23^{\text {rd }}-27^{\text {th }} 2019$, in Denpasar; The $1^{\text {st }}$ Ken Steven International Choral Festival, held on August, $23^{\text {rd }}-25^{\text {th }}, 2019$, in Medan; The $4^{\text {th }}$ North Sumatra Choir Competition held on Agustus $27^{\text {th }}, 2019$, in Parapat North Sumatra; Jakarta World Choir Festival held on October, 24th$27^{\text {th }}, 2019$ in Jakarta; Karangturi International Choir Competition held on November, $13^{\text {rd }}-16^{\text {th }}$ November, 2019 in Semarang, and $3^{\text {rd }}$ Dumai National Choir Festival, 14-15 November, 2019 in Dumai, Riau. Although held in Indonesia, they were not used as the sources of data since data of the folksong arrangement are not complete.

The data collection procedures were done as follows. Firstly, identifying the arrangement. i.e. the title, the origin, and the arrangers' name. The sources of data were collected from the choir competition event and from the social media of the event (e.g. Whatsapp group, Facebook, Instagram, Google, and Youtube). The identification was done through the document study and statistic method. Secondly, interviewing the arrangers, choir leaders and the musicians working for the choir competitions.

\section{Results and Discussions}

The findings answer the three research questions. First, what is the trend of song-arrangement choice in terms of title, arranger, and origin of the folk song? Second, what are the characteristics of folk song arrangement refer to the most popular folk songs performed in the choir competition? Third, what are the roles and relationship between the arranger and the choir competition committee?

\section{The Trends of Folk Song Arrangement}

This part attempts to answer the first research question. It consists of the trend of titles, arrangers and the origins of the folk songs in the choir competitions, 2019. 
The Trend of Titles of Folk Song in the Choir Competitions, 2019

The research finding showed that there were 55 titles of folk song arrangement performed in the six choir competitions, folk song category within 2019. The most frequently chosen was Ken Steven's "Cikala Le Pong Pong". It was performed 10 times in 5 choir competitions. The next most frequently chosen titles was Avip Priyatna's and Agustinus Bambang Jusana's "Janger". It was performed 5 times. Ken Steven's "Hela Rotan" was performed 4 times. The forth most frequently chosen titles were the following four titles: Budi Susanto Yohanes "Ugo Ugo", Budi Susanto Yohanes "Tari Sanghyang Dedari", Ken Steven's "Paris Barantai”, Josu Elberdin's "Soleram", and Amril Huda's "ErangErang Subuh". The fifth titles were performed 2 times, Budi Susanto Yohanes "Luk Luk Lumbu", Budi Susanto Yohanes "Jaranan" and Bagus Syariez Paradika's "Kicir-kicir". The rest 43 titles were performed once.

The fact that Ken Steven's "Cikala Le Pong Pong" was the most popular title needs to be dug out in details.

As presented in the table 1, "Cikala Le Pong Pong" was performed in 5 competitions, but not in The $1^{\text {st }}$ Toraja Highland Choir Festival. In the $7^{\text {th }}$ Satya Dharma Gita Choir Festival dan the $3^{\text {rd }}$ Choral Orchestra Folklore Festival, this song was performed by 3 group-participants. In Brawijaya Choir Festival it was performed twice. In Rhapsodie Indonesia Choir Festival and Lomba Paduan Suara Universitas Gajah Mada, it was performed once. Why is the data important then? It shows that Ken Steven's "Cikala Le Pong Pong" is likely to be performed in the Choir Competitions.

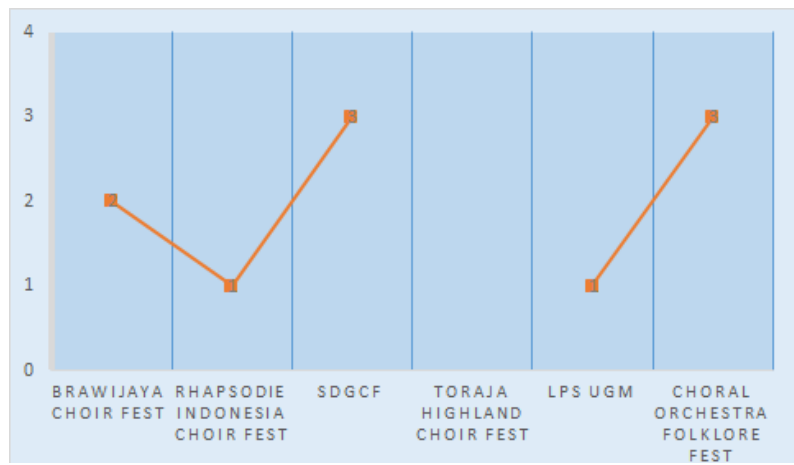

Table 1: Frequency and mode of "Cikala Le Pong Pong" arrangement.
The Trend of Arranger Names of Folk Songs in Six Choir Competitions, 2019

The last two paragraphs have discussed the folk song titles. This section discusses the trend of arranger names.

The data revealed that Budi Susanto Yohanes was the most popular arranger among the 36 arrangers in the choir competitions. There were 15 arrangement of his works used in the competitions. Among the 11 titles were "Ugo-ugo" (from Banyuwangi, East Java), "Keraben Sape Madura" (from Madura, East Java), "Janger" (from Bali), "Luk Luk Lumbu" (from Banyuwangi, East Java), "Seblang Shubuh" (from Banyuwangi, East Java), "Meplalian" (from Bali), "Jaranan" (from Central Java), "Yamko Yambe Ramko" (from Papua), "Tari Sanghyang Dedari" (from Bali), and "Ma Rencong Rencong" (from South Sulawesi). It means that there are songs that were performed more than once in the competitions. As seen from table 2, Yohanes' work were performed in four competitions, but not in the Rhapsodie Indonesia Choir Festival and the 1st Toraja Highland Choir Festival.

The next popular arranger was Ken Steven with his 6 works of arrangement. The arrangers whose arrangement had also been used in the

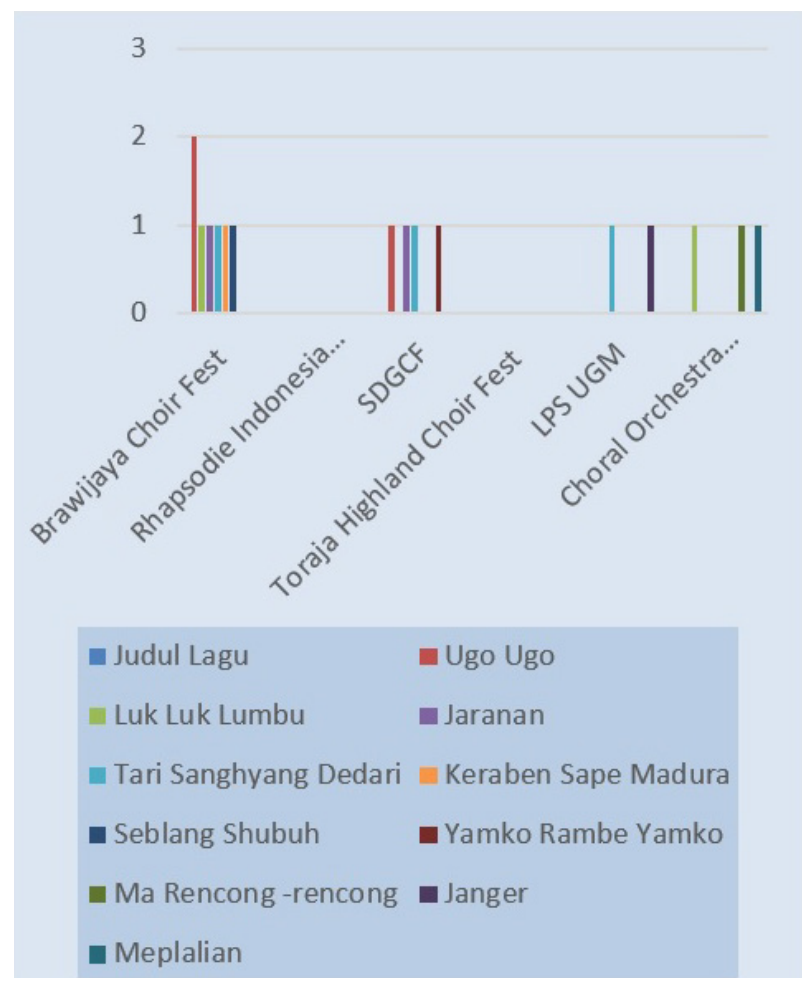

Table 2: The frequency of Budi Susanto Yohanes' arrangement. 
competitions for about twice or three times were Agustinus Bambang Jusana, V. Manungsong, Amril Huda, Bagus Syariez Paradika, Farhan Reza Paz, and Agastya Rama Listya.

Why does this information become important? Because it can realize the idea of profiling the arrangement of Folk Song Category as proposed in a national choir competition "Kompetisi Paduan Suara Universitas Parahyangan" in 2001. In brief, it can make the dream come true. This is confirmed by Avip Priyatna, the choir leader as well as the artistic director of the festival:

"Yes, in 2001, such a folk song category had already been popular in some international choir competitions, but not in the national ones. It was just done for the first time in "Kompetisi Paduan Suara Universitas Parahyangan" in that year. At that moment, it was not easy to find the arrangement of folk songs for the competition. Therefore, conducting similar folk song category in choir competition is to call for more arrangers to participate in such a competition. By so doing, there will be a new nuance in such a competition" (source: interview, April 14 $4^{\text {th }}$, 2019).

Now, the song arrangement is considered high in numbers and varied in terms of titles. It was proved from the number of 55 titles and of 36 arrangers used in the folk song category in choir competitions in 2019 as investigated in this study. As traced from its history, the folk song arrangement began to become popular around 1990. "At that time, there were many choir groups performing folk songs arrangement in national choir competition. At that time, there was not a folk song or folklore category to be existed in a choir competition" said Agastya Rama Listya, a componist (source: interview, January, 15, 2020).

The folk song arrangement was getting more popular in 2000s. It was indicated from the presence of Budi Susanto Yohanes "Luk Luk Lumbu" in Festival Paduan Suara Institut Teknologi Bandung in 2002. At that time, it was performed by Gracioso Sonora Choir from Malang and led by Budi Susanto Yohanes himself (Yohanes, Interview:
August, 27, 2019). Up to know, the arrangement is still in use in any choir competition.

Apart from the 10 titles presented in table 2, Budi Susanto Yohanes has been very active composing folk songs arrangement. Some other titles are "Tari Kembang Soka" (from Ponorogo, East Java), "Si Patokaan" (from North Sulawesi), "Bungong Jeumpa" (from Aceh), "Anging Mamiri" (from Makassar, South Sulawesi), "Cublak-cublak Suweng" (from Central Java), "Piso Surit" (from Karo, North Sumatera), "Soleram" (from Riau), "Rasa Sayange" (from Maluku), "Sudah Berlayar" (from Maluku), "Tardigadingdangdo" (from Tapanuli, North Sumatera), "Wak Wak Gung" (from Betawi, Jakarta), "Ahtoi Porosh" (from Dayak, Kalimantan), "War kankarem-Morinkin" (from Biak, Papua), "Gai Bintang" (from Madura), dan "Sik Sik Batumanikam" (from Batak, North Sumatera).

Referring to his performance from 2002 and to his works of arangement, Budi Susanto Yohanes shows his qualification in the world of folk song choir arrangement. Furthermore, within these 10 years, He has become a judge not only in national but also international level of choir competitions.

Almost similar to Budi Susanto Yohanes, Ken Steven has an interest in folk songs arrangement.

"The choir arrangement that I have done is more on folk songs than the other musical genres. Arrangement and culture are indeed my interest. The first song that I arranged was "Sik Sik Batumanikam". Initially, I did not understand the language, but I learnt it and then love it, love the culture, yes love both the underlying meaning of the lyrics and its philosophy" (Steven, Interview: December 18, 2019).

His other works beside "Cikala Le Pong Pong" are "Benggong" (from Manggarai, East Nusa Tenggara), "Hela Rotan" (from Maluku), "Paris Barantai" (from South Kalimantan), "Lancang Kuning" (from Riau), "Nuusuk Asib" (from Bali), "Tokecang" (from West Java), "Prau Layar" (from Central Java), "O Tano Batak" (from North Sumatera), "Jangan Undure" (from Maluku), "Sitaro Tillo" (from North Sumatera), "Lisoi" (from North Sumatera), "Alusi Au" (from Batak, North 
Sumatera), "Kampuang Nan Jauh di Mato" (from Minangkabau, North Sumatera), "Mempalyangan" (from Bali), "Hirameya" (from Gorontalo, North Sulawesi), "O Ina Ni Keke" (from Minahasa, North Sulawesi), and "Batak Medley for TSBB" (from North Sumatera). His curiousity toward such folk songs motivated him to arrange many other folk songs. Since his folk song arrangement used in a choir competition, his arrangement of folk songs is easily found in many choir competitions.

Indeed, the reknowned arrangers, Budi Susanto Yohanes and Ken Steven have contributed a lot in the repertoire of Indonesia folk songs choir arrangement. They admitted that their contribution was inspired by their senior arranger, late Paul Widyawan (1945-2019).

Paul Widyawan was popular as all a composer, instructor, performer, and teacher. The whole life, he was devoted himself to develop Catholic liturgical music in Pusat Musik Liturgi (PML) or liturgical music center, Yogyakarta. He also documented folk songs choir arrangement in books of score published by PML. The books are "Ondel-Ondel" (1976), "Bolelebo" (1979), "Kambanglah Bungo" (1984), "Domindow" (1988), "Dami Piranta" (1991), "Mutiara Samudera" (1996), "Folksong" (2014), and "Sate Embik" (2014). The books contain different number of arrangement. Apart from the collection of scores, he also produced a nine-volume book entitled "Nusantara Bernyanyi". It is a compilation of hundreds of Indonesian folk song for solo voice. Not only dedicated himself to such local wisdom, He also integrated Christianity values into such local concept (Wahyudi, Interview, March 24, 2019).

\section{Trend of Folk Songs Origin in Six Choir Competitions, 2019}

Being motivated by what Paul Widyawan has done, it is important to identify the origin of Indonesian folk songs performed in six Choir Competitions, 2019.

The table reveals that the most frequently performed folk songs were from Java and Madura. Sumatera was in the second rank. Bali, Lombok and Sumbawa, Papua, Kalimantan, Sulawesi, Nusa Tenggara and Maluku were in the following ranks.
The category of region above was based on the New Grove Dictionary of Music and Musician (Yampolsky, 2002: 275).

The regions in the table seem to represent big islands in Indonesia but not yet represent the trend of creative arrangement based on their origin .i.e. province and culture (ethnic). In addition, the table does show the existence of folk songs in the choir competitions, 2019, but does not the arrangers' interest in arranging the folk songs. However, it at least can tell that folk songs from Java-Madura have become a particular interest for the ethnomusicologists.

Among the number of titles and arrangers, a question may be raised whether the arrangers come from the region where the folk song is from. The answer is absolutely "no". Budi Susanto Yohanes is from Blitar, East Java. Similarly, Ken Steven is from Binjai, North Sumatera. This phenomenon suggests two things: individual interest in ethnic musical elements and external factors. Multicultural understanding mediates this phenomenon (Ganap, 2012). Indeed, the creation of works originating from ethnic traditions cannot be separated from the realm of original culture, so it is hoped that the arranger or composer who comes from the cultural realm will produce works of music that represent the original culture. In respond to this phenomenon, Poedji Soesila, musician says that:

"For a competition, I usually arrange a song by a request from a choir group-participant. There are two options for such a request. First, the participant decides the title and second, I decide it. Usually, if the song is from Java, I decided the title and arrange the song suitable

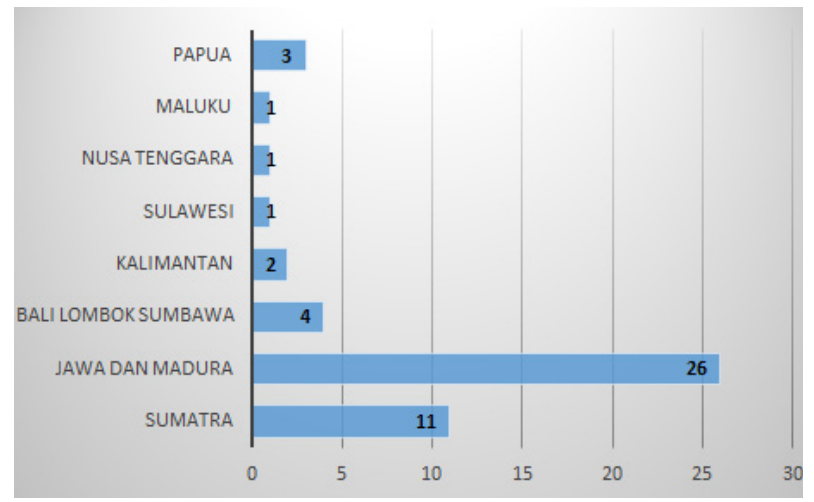

Table 3: The Frequency of The Origin of Folk Song Performed in Six Choir Competitions, 2019 
with my musical style. However, if the song is not from Java, the participant would decide the title" (Soesila, interview, March 23, 2020).

Similar to Soesila, Ken Steven has a similar experience. He said that "many choir groupparticipants send requests for me to arrange the folk song for them." (Steven, interview, December, 19, 2019). The interview result show that the choice of folk song titles and origin are not only about the arranger's interest but also because of "agents" requesting to the arranger. Such "agents" attract musical sociologists' interest.

\section{The Use of Musical Elements in Folk Song Choir Arrangement}

Such a creative process of arranging folk song for choir competitions has elaborated musicological perspective and folk song elements. Again the question is whether such an arrangement can express the culture where the folk song is originated?

Daniel Dasalak, the coach of Karunia Children and Youth Choir, Jakarta who chose "Cikala Le Pong Pong" arranged by Ken Steven in Rhapsodie Indonesia Choir Festival said that this song is competitive and challenging (Dasalak, interview, April 15, 2019).

"Cikala Le Pong Pong" is a rhythmic song which is very Bataknese. To teach such a rhythmic song was very challenging especially for my "kids" who never learnt such a rythmic and ethnic music. For me, it was something new, because what we had performed so far were sacred and gospel music. So, their performance on "Cikala Le Pong Pong" is more to an appreciation. Fortunately, the arranger of this song is a friend of mine so that I can contact him easily" (Dasalak, interview, April 15, 2019).

Ken Steven's arrangement on “Cikala Le Pong Pong" is homophonic and emphasizes on body percussion rhythm. "Cikala Le Pong Pong" folk song contains a message from parents to their daughter going to get married. The parents give advice for their daughter to do good for her happiness. The basic tone of this song is $\mathrm{C}$ which is expected to enable singers to express the song of hope (of parents) well. The arrangement format is mixed of soprano, alto, tenor and bass (SATB). In some parts, the voice is classified into SAATTB, SSATTB, and SSAATTBB. There are some sentences to be accentuated in the lyric "Cikala Le Pong Pong". The phrase "Cikala Le Pong Pong" is repeatedly sung five times in the introduction so the vocal tension gets increased.

In figure 1, "si manguda begendari enle dak mangkabari" means that nowadays teenagers wander for no purposes. The last syllable of "mangkabari" is glissando. The ornament notation like glissando gives a dramatic impression the same as the meaning of the song. i.e. telling the bride be faithfull wife. Cord progression in bar 39-41 is $\mathrm{G}^{\text {add11 }}-\mathrm{Am}^{\text {sus2 }}-\mathrm{Am}$ which presented a cord variation as in modern arrangement technic, not a conventional one.

In bar 42-45, cord progression Am-AmAm-E7 happens as a homophone sound with body percussion. The complexity of the arrangement lies on the rhythm vocalized by unpitched body percussions. The body percussions. i.e., stomping and clapping were done by all voices in one bar without any lyric so the rhythm is very clear in part B' (figure 2).

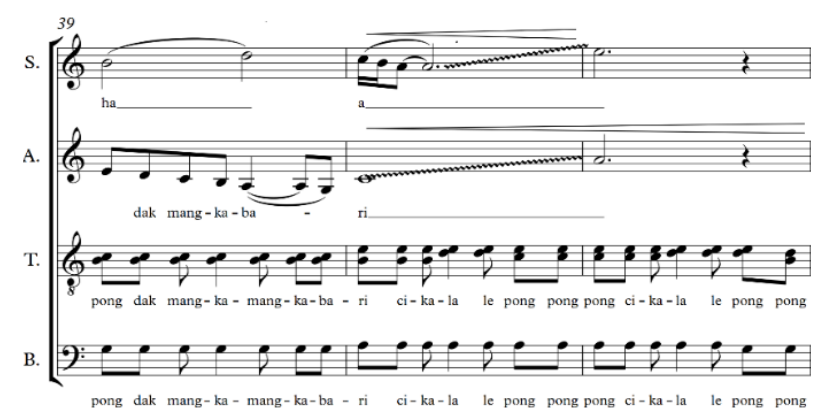
Figure 1: Bar 39-41 "Cikala Le Pong Pong". (Transcript: Ken Steven, 2017)

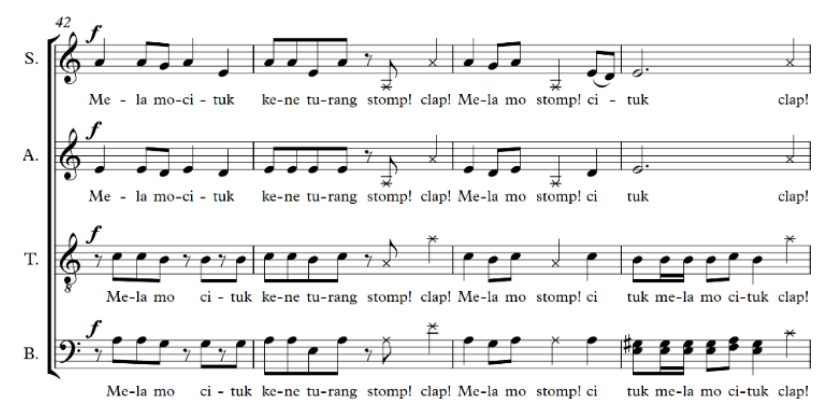
Figure 2: Bar 42-45 "Cikala Le Pong Pong". (Transcript: Ken Steven, 2017) 
It is an arrangement melody with no instrumental accompaniment (acapella) which melody is dominated by female voices (sopranos and alto). As for male voices (tenor and bass), they accompany the female voice in some parts with the phrases "dum du rudum", "kir pong" and they were sung repeatedly in a variation of rhythm.

Piece of notation in figure 3 indicates an interlocking among soprano, alto and tenor. As for bass, it remains rhythmic to keep the tempo. In bar 65 glissando takes place for soprano (1). Body percussion with clap, snap, stomp appear in different beat for each voice. The end of bar 65-67 is dominated with cord harmony Amsus2 and Am7sus 2 which is done consecutively for each bar. A modification in each voice is also done for rhythm development dynamic and musical variation like glissando, appoggiatura, snap/stomp. Such modification and musical variation make the arrangement rich and alive. The rhythm is not only clear in the body percussion, but also in the lyrics. For example, the emphasis on vowels in "ci-ka-la$l e$ " and in some other syllables " $m o, g i, n e i, d a, r i$, $k o, l i, m o, k a, n e, l e$, etc". It seems that the words used in Batak Pak Pak Dairi language have more vowels.

The sentence in Batak Pak Pak Dairi language "kade mo keleng atemu anak maholi man pabing abingen" the one you love is a handsome man to live with. "Mela mo cituk kene turang, ulang ulaken kene male", tells not to wander around or you will ashamed of doing that. The phrase Cikala Le Pong Pong does not have any meaning, but cikala refers to kincung flower or combrang flower and the word le pong pong refers to la..la..la..(whistling). Pong pong is a kind of rythmic ornament because pong pong is the smallest gong (a musical instrument) among the

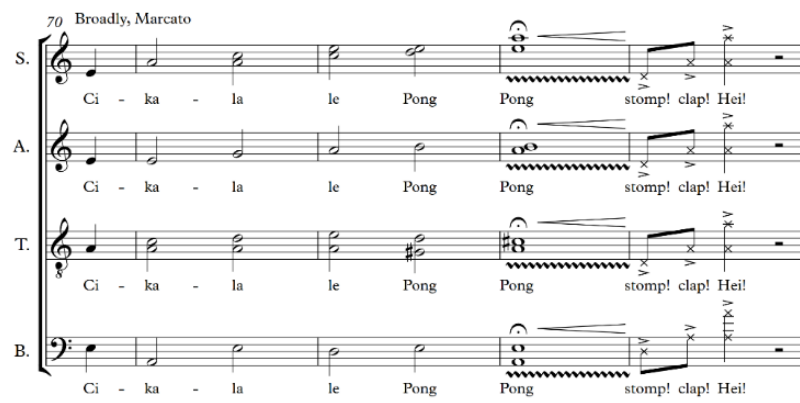

Figure 3: Bar 65-67 "Cikala Le Pong Pong". (Transcript: Ken Steven, 2017) other musical instruments in Batak Pak Pak Dairi society (Takari, 2005: 19). The use of unpitched syllables is also used in the ending of "Cikala Le Pong Pong" to emphasize the stomping effect.

The arrangement contains three parts: introAB-interlude-A'B'-interlude-C-ending-coda. As known in the creative process of arrangement, parts or sentences of music are indicated with A-B-C$\mathrm{D}-\mathrm{E}$ and an arranger commonly uses the common patterns: intro, interlude, and coda (Sanjaya, 2013: 43). Part A' is repeated using a variation that clearly represent part A. Similarly with part B', repeated from part B. Part C is in the third stanza but with a different melody. In addition, part by part of this song is not arranged symmetrically as how each stanza in such a folk song should be (Machlis, 1977: 67).

Coda (bar 70-75) Ci-ka-la-le-pong-pong is performed in homophone with marcato expression and followed with vibrato, stomping, clapping and interlocking "hei" in the end, and then with silent sign. The word "hei" followed with the silent sign ends the arrangement, that is to give a "surprise" impression.

Ken Steven's arrangement of "Cikala Le Pong Pong" is rich in processing between parts, rhythm, and also harmony. Dynamic in music is strengthened with signs of freely, chant like and allegro, dance like, and crescendo in some parts. From the view of musicology, the elements of folk song consist of two things: melody and lyric (Titon, 1992: 169). As the arrangement principle, an arrangement can change the form but not the substance of melody and lyrics (Purnomo, 2018). Similarly, the arrangement of "Cikala Le Pong Pong" does not change the melody and lyrics. As viewed from the perspective of an arranger, some musical

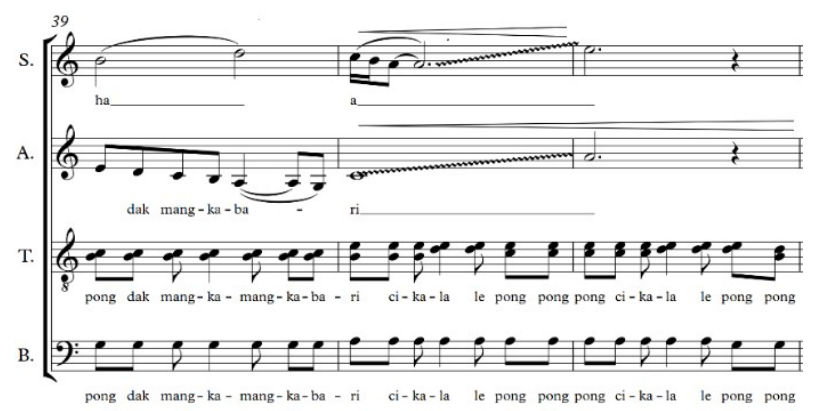

Figure 4: Bar 70-74 "Cikala Le Pong Pong". (Transcript: Ken Steven, 2017) 
elements of Ken Steven's arrangement of “Cikala Le Pong Pong" represent the culture of Batak Pak Pak Dairi. Any arranger, as the arrangement convention says, is allowed to be creative in giving artistic values his/her work of arrangement. So this can be a crosscultural activity for the arranger, a transcendency from musicology or ethnomusicology into an aesthetic consciousness. This also happens to Ken Steven and Budi Susanto Yohanes. In this way, whether it is a western or eastern music is not longer debated (Sunardi, 2012: 255).

\section{The Relationship between Arranger and The Committee of Choir Competitions}

This part discusses the finding of the third research question: what are the roles and relationship between the arranger and the choir competition committee? In arranging choir, an arranger follows artistic requirements determined by the committee. In Rhapsodie Indonesia Choir Festival, the committee set three requirements: a folk song category, traditional custom, and choreography. The last two are for the stage performance. In "the $7^{\text {th }}$ Satya Dharma Gita Choir Festival”, the committee required a single requirement: a folk song category. Such requirements indicate the committee's political behaviours that require participants to meet the requirements of the choir competition. Whether the arrangement of folk songs is really folk songs, the committee seem not to really take it into account. According to Tommyanto Kandisaputra, the leader of Bandung Choral Society, the artistic director of "Bali International Choir Festival", of "Rhapsodie Indonesia Choir Festival", "Jakarta World Choir", and "Makassar Choir Festival":

"As long as the folk song represents its ethnicity, it is enough. We do not really make the difference of folk song and folklore a matter. Such a discussion would be the concern of musicology and ethnomusicology. Our concern is on the choir performance, not more (Kandisaputra, interview, October, 28, 2019).

The statement seems to be a paradox. On the one hand, a committee has set rules to be obliged by participants. On the other hand, the arranger makes use of the competition for an opportunity to be creative in arranging the folk song without paying much attention to the rules.

The previous paragraph is about artistic requirements in a choir competition that help us see the relationship between arrangers and the choir committee. Besides the artistic requirement, there is also a non artistic requirement in a choir competition. Commonly, folk song, patriotic song, hymn, and songs with single melody can be used without any permission from the composer because he/she has already become a public domain (Ostrander, 1986: 252). But if it is not public domain, like the arrangement of folk song for choir competition like this, it should have the arranger's permission.

"The copyright of the repertoire is the responsibility of the participants. The committee is not responsible for the copyright and copy of repertoire that will be used" (Guidance Book, $7^{\text {th }}$ Satya Dharma Gita Choir Festival).

That is about a copy right in a choir competition. The issue of copy right and legal protection of work of music has been treated well. Operationally, the copy right can be obtained in two ways. First is by getting a letter of permission from the composer/arranger. Second is by purchasing the score from the publisher. In this case, Daniel Dasalak, the leader of Karunia Children and Youth Choir, decided to take the first way since he has a close relationship with the arranger.

As for Paul Widyawan, Wahyudi, his assistant said that the copy right of his arrangement was under Pusat Musik Liturgi (PML) or liturgical music center so PML is the one that publishes the copy right letter:

“All the copy right of Paul Widyawan's work is under PML. This is to protect his work. Many asked for how much they should pay for using his work. We, in this case, leave it up to them. We never charge particular amount of money for that. If they ask for a copy right permission, we would give a permission letter without any complicated procedures. We are glad to be informed that his work is performed. More to that, many people have 
already had his folk song arrangement books" (Wahyudi, interview, March 9, 2020).

This kind of copy right permission in the form of letter is not merely a letter but more to a financial matter. Wahyudi's statement not only shows a protection to one's work but also a commodity in a choir competition. As commonly stated as the requirement of a choir competition (e.g. of Satya Dharma Gita Choir Festival), such a non artistic requirement also provides a financial right for the arranger.

That a work of music can be a commodity is reflected in the procedures of purchasing a music-score book in a publisher. The publisher, the same as a book publisher, provides the catalogue of title, arranger's name, genre, the vocal ranges, composition specification, duration, vocalization, and price. Some international music publishing companies like Earthsongs (USA), Carus-Verlag (Germany), Kontrapunkt (Hungary) and Singapore Choral Research Center (Singapore) has published the works of Indonesian composers.

Those interested in music scores can contact the contact person in the publisher's website like: www.earthsongchoralmusic.com, www.sheetmusic plus.com, www.jwpepper.com or in the arranger's website like: www.kensteven.com. The presence of publishers that provide arrangers' music scores shows economic activities. This should not be something debatable since it is stated in copy right law no. 28. 2014. However, the arranger in this case does not always think about money:

"For me as an artist, I work for an idealism. When I was working, I was not thinking about money. That is not the goal. But if I get money, that's a fortune. Yes, I am fortunate. My work is performed in the choir and liked by people (Steven, interview, December 18, 2019).

Steven's statement shows that he is ready for both financial right or not. This is because sometimes an arranger does not earn enough money from the choir participants for the arrangement copy right. The reasons given are because of lack of money or complicated procedures for joining the choir competition.
"Many choir group-participants have a financial problem for joining a choir competition. Therefore, they have to do fund rising in many ways" (Steven, interview, December $18,2019)$.

Such a case shows that an arranger's financial right is not fulfilled well. It also shows that there is an imbalance between one's moral right and one's financial right. On the one hand, one's creative work of music has been recognized by a copy right law. On the other hand, it has not got an appropriate financial consequence. However, the fact shows that the 36 arrangers whose work was performed in the choir competitions in 2019 keep showing their existential spirit.

\section{Conclusion}

The findings of research question one revealed the most popular arrangement, arranger, and origin of folk song in the six Choir Competition in 2019. First, the most frequently used arrangement was Ken Steven's “Cikala Le Pong Pong”. Second, the most popular arranger was Budi Susanto Yohanes, an arranger with many works of arrangement. He has worked for music arrangement for about 20 years. He is also popular in the field of choir competitions and as a choir judge. Third, Java and Madura were the origins from which most of the folk songs were performed in the competitions. Song from those region have also inspired many arrangers. This repertoire of folk song choir arrangement shows a variety of ethnic groups and a variety of arrangers. It also shows how the folk songs existence has 'moved' beyond their origin to evolve to be various works of arrangement. The choir competition committee becomes an agent that can introduce and/or popularize the arrangers' work of arrangement.

The outcome of the second question of the research showed that Ken Steven's "Cikala Le Pong Pong" was the most popular one due to its unique arrangement in the form of vibrant music rhythm and body percussion. The arrangement is characteristed in a homophonic texture, a structure of intro-AB-interlude-A'B'-interlude$\mathrm{C}$-ending-coda, and having rich ornamentation. 
Such modification made it a rich variation and challenging to be sung. This arrangement expresses a planned and serious effort to represent the musical character of Batak Pak Pak Dairi.

The findings of the third research question revealed that an arranger is not merely a composer, but also as a successive link in any choir competition. Without any folk song arrangement, there would be no folk song or folklore category in a choir competition. So the arranger here is the first key agent in a systemic social-organization mechanism in a choir competition. In addition, an arranger's creativity shows his/her existential function to survive. To be more political, an arranger is considered as both a creative agent that empowers ethnic musical elements to his/ her choir arrangement and as the beneficiary of a choir competition mechanism. In the view of sociology of music, this phenomenon suggests that music is not only a sonorous thing, but also musical behaviour which is socially a practical activity. This study can be followed up with investigating the particularity of folk song choir composition from the first time folk song category was performed in a choir competition up to now. This will be helpful to produce a periodization of folk song choir arrangement's and an arranger's particularity. This study is limited to six choir competitions in 2019, so is necessary to conduct more extensive research in other competitions.

\section{Acknowledgements}

This study was a part of my doctoral dissertation entitled "Artistic Negotiations in Choir Competitions Folklore Category". I owe a very important debt to the following resource persons as well as teachers in the field of research: Agastya Rama Listya, Avip Priyatna, Budi Susanto Yohanes, Daniel Dasalak, Ken Steven, Poedji Soesila, Tommyanto Kandisaputra and Wahyudi. Special thanks also to Nyak Ina Rasuki and Lono Simatupang for discussing the embryo of my dissertation. Last but not least, I am indebt to Rosalia Meita Widhiardanti (Ambarawa), mas Hadrianus Anang Brotoseno (Malang), mas Yosafat Rannu Leppong (Surabaya), mbak Athitya Diah
Monica (Yogyakarta), tante Iin Astanada and Ester Komalig (Salatiga) for their help during my data collection and to Duth Simatupang (Medan) for translating the lyrics of "Cikala Le Pong Pong".

\section{References}

\section{Journal Article}

Artanto, M. (2016). Mencermati Transit dan Transition dalam Aransemen Musik Nyanyian Negeriku Karya Singgih Sanjaya. Kajian Seni, 2(2), 132-150. https://doi.org/https://doi. org/10.22146/jksks. 12141

Dwi Arini, S. H., Supriadi, D., \& -, S. (2015). Karakter Musik Etnik Dan Representasi Identitas Musik Etnik. Panggung, 25(2), 177188. https://doi.org/10.26742/panggung. v25i2.7

Firmansyah, Simatupang, G. R. L. L., Kusmayati, H., \& Sushartami, W. (2019). Aksiologi Musikal pada Pertunjukan Tari Tradisional Linda dalam Ritual Adat Keagamaan Karia di Daerah Kabupaten Muna Provinsi Sulawesi Tenggara. Resital, 20(3), 132-149. https://doi. org/10.24821/resital.v20i3.3817

Ganap, V. (2012). Konsep Multikultural dan Etnisitas Pribumi dalam Penelitian Seni. Humaniora, 24(2), 156-167. https://doi. org/https://doi.org/10.22146/jh.v24i2.1058 Lapian, Alrik and Mulyana, A. R. (2017). Musik Vocal Etnik Minahasa Budaya Tradisi. Dewaruci, 12(2), 71-78. https://doi.org/ DOI: https://doi.org/10.33153/dewaruci. v12i2.2529

Martarosa, M. (2017). Musik Bandar Dalam Perspektif Seni Budaya Nusantara. Resital: Jurnal Seni Pertunjukan, 18(1), 27-42. https://doi.org/10.24821/resital.v18i1.2444 Omega, E., Simatupang, G. R. L. L., \& Koapaha, R. B. (2019). Penyajian Lagu Dewa Ayu Janger oleh Immanuel Choir. Kajian Seni, 06(01), 68-80. https://doi.org/https://doi. org/10.22146/jksks.51704

Purnomo, W. (2018). A Hingga K Tahap Dasar Mengaransemen Nyanyian Untuk Paduan Suara. LAKON, Jurnal Pengkajian \& Penciptaan Wayang, XV(1), 56-68. 
Ronaldi and Sukerta, P. M. (2013). “ Bansi Rang Solok " Music Composition Of ( Re Interpretasi Tradisi ). Dewaruci, 12(1), 17-21. https://doi.org/https://doi.org/10.33153/ dewaruci.v12i1.2516

Rustim, Nugraha Ch.R., W., \& Simatupang, G. R. L. L. (2019). Interaksi Sosial Tradisi Bagurau Saluang Dendang Minangkabau di Sumatera Barat. Resital: Jurnal Seni Pertunjukan, 20(1), 36-51. https://doi.org/10.24821/resital. v20i1.3509

Rustiyanti, S. (2017). Aluang Bunian Karawitan Minangkabau dalam Pamenan Anak Nagari dari Penyajian Bagurau ke Presentasi Estetik. Resital: Jurnal Seni Pertunjukan, 16(2), 104-115. https://doi.org/10.24821/resital. v16i2.1510

Sanjaya, R. M. S. (2013). Metode Lima Langkah Aransemen Musik. Promusika, 1(1), 3349. https://doi.org/10.24821/promusika. v0i0.538

Santosa. (2015). Pusat Sumber Musik Dunia Di ISI Surakarta: Peran, Masalah dan Kebijakan. Dewaruci, 10(1), 22-28. https:// doi.org/10.33153/dewaruci.v10i1.2142

Satriana, R., Haryono, T., \& Hastanto, S. (2014). Kanca Indihiang sebagai Embrio Kreativitas Mang Koko. Resital: Jurnal Seni Pertunjukan, 15(1), 32-42. https://doi.org/10.24821/ resital.v15i1.798

Syafputra, Y., Penciptaan, P., \& Musik, S. (2017). Pengalaman Empiris Menjadi Sebuah Ide dalam Penciptaan Musik. Dewaruci, 12(1 Juli), 31-39. https://doi.org/10.33153/ dewaruci.v12i1.2518

Takari, M. (2005). Kesenian di Sumatera Utara: Beberapa Pemikiran Mengenai Arah dan Pengembangan Fungsinya. https:// www.etnomusikologiusu.com/jurnaletnomusikologi-dan-hoho.html

Tindaon, R., Simatupang, G. R. L. L., \& Ganap, V. (2018). Andung-Andung Mate di Ranto. Resital, 19(1), 46-53. https://doi.org/https:// doi.org/10.24821/resital.v19i1.2451

Zulkarnain Mistortoify, Timbul Haryono, L. L. S. dan V. G. (2010). Kejhungan: Gaya Nyanyian Madura dalam Pemaknaan Masyarakat
Madura Barat pada Penyelenggaraan Tradisi Remoh. Resital: Jurnal Seni Pertunjukan, 11(1 Juni), 1-14. https://doi.org/10.16309/j.cnki. issn.1007-1776.2003.03.004

\section{Book}

Boyd, M. (2002). Arrangement. In S. Sadie (Ed.), The New Grove Dictionary of Music and Musican (4th ed.). London: Macmillan Publisher Ltd.

Dasilva, F. A. B. D. D. (1984). The Sociology of Music. Notre Dame: University of Notre Dame Press.

Machlis, J. (1977). The Enjoyment of Music (4th ed.). New York: W.W. Norton \& Company.

Ostrander, A. E. . D. W. (1986). Contemporary Choral Arranging. New Jersey: Prentice-Hall.

Simatupang, G. R. L. L. (2013). Pergelaran : Sebuah Mozaik Penelitian Seni-Budaya. Yogyakarta: Jalasutra.

Small, C. (1998). Musicking: The Meaning of Performing and Listening (pp. 1-230). Connecticit: Wesleyan University Press.

Sunardi, S. (2012). Vodka dan Birahi Seorang Nabi. Yogyakarta: Jalasutra.

Titon, J. T. (1992). Music, Folk, and Tradition. In R. Bauman (Ed.), Folklore, Cultural Performance, and Popular Entertainment (pp. 167-171). Oxford: Oxford University Press. Yampolsky, P. (2002). Indonesia. In The New Grove Dictionary of Music and Musican (Volume 4, pp. 275-371). London: Macmillan Publisher Ltd.

\section{Informant}

Agastya Rama Listya (52 years old). Arranger, judge, lecturer at Music Department, Satya Wacana Christian University, Salatiga, Central Java.

Avip Priyatna (57 years old). Arranger, judge, a Music Director and Conductor of Jakarta Concert Orchestra and Batavia Madrigal Singers (BMS), Jakarta.

Budi Susanto Yohanes(39 years old). Arranger, judge, conductor for various choirs.

Daniel Dasalak (42 years old). Conductor of Ka- 
runia Children and Youth Choir from GPIB Jakarta since 2007 and many choir in Jakarta.

Ken Steven (26 years old). Arranger, judge, a teacher in Medan, North Sumatra.

Poedji Soesila (51 years old). Arranger, judge, lecturer at Music Department, Satya Wacana
Christian University, Salatiga, Central Java. Tommyanto Kandisaputra ( 53 years old). Founder and artistic director of Bandung Choral Society in 2000.

Wahyudi (52 years old). Live and work in Pusat Music Liturgi Yogyakarta since 1988. 